Article

\title{
Fool's Gold: Understanding Social, Economic and Environmental Impacts from Gold Mining in Quang Nam Province, Vietnam
}

\author{
Nhi Nguyen ${ }^{1, *}$, Bryan Boruff ${ }^{1}$ and Matthew Tonts ${ }^{2}$ \\ 1 UWA School of Agriculture and Environment (M004), University of Western Australia, 35 Stirling Highway, \\ Crawley, Perth, WA 6009, Australia; bryan.boruff@uwa.edu.au \\ 2 Faculty of Arts, Business, Law and Education, University of Western Australia, Crawley, \\ Perth, WA 6009, Australia; matthew.tonts@uwa.edu.au \\ * Correspondence: nhi.nguyenba@research.uwa.edu.au; Tel.: +61-8-6488-2700; Fax: +61-8-6488-1037
}

Received: 26 February 2018; Accepted: 24 April 2018; Published: 27 April 2018

\begin{abstract}
Extractive industries are often claimed to contribute to both poverty reduction and economic growth. Yet, there is also a body of research that suggests natural resource dependence can result in limited development, environmental degradation and social upheaval. This paper examines differences in the socioeconomic and environmental state of mining and non-mining communities in rural Vietnam in order to understand the extent to which mining contributes to livelihood development and socioeconomic well-being. In particular, we examine the role that "corporate social responsibility" (CSR) plays in supporting community development in Phuoc Son and Phu Ninh districts, Quang Nam province. Content analysis of newspapers, government documents and mining company reports provided a contextual overview of mining operations and community relations in each study area. Semi-structured interviews were used to collect information from local and regional stakeholders to further understand perceived impacts of mining operations on local communities. Our study finds that in comparison to non-mining communities, communities with active mines demonstrated increased job development, decreased poverty rates, enhanced infrastructure and social development along with increased incidences of CSR initiatives. However, a number of adverse effects from mining activities were reported including environmental degradation (e.g., deforestation, water pollution, etc.) increased criminal activity and drug addiction. Dependence on mine-related employment in local communities becomes acutely apparent when temporary mine closures result in widespread unemployment. Local governments may be the greatest beneficiaries of mining with increased tax revenues and enhanced management potential of leased land. Non-mining communities without direct benefits from mining activities maintained economic diversity and were therefore more resilient to economic shocks such as nearby mine closures.
\end{abstract}

Keywords: mining; socioeconomic well-being; corporate social responsibility; environmental degradation; Vietnam

\section{Introduction}

The impacts of natural resource extraction, including mining, on local communities have been a longstanding interest of social scientists. Scholarly inquiry has identified that extractive industries contribute to both poverty reduction and economic growth [1,2]. Yet, there is also a body of research that indicates natural resource dependence can result in slow economic growth, environmental degradation and social upheaval [3-5].

Research on mining and development has typically focused on three areas: the impact of mining on governance, national economics and growth (e.g., [3,6-8]); the relationship between mining and 
community-level social, economic and environmental change (e.g., [9-11]); and the development of socioeconomic indicators measuring mining impacts (e.g., [12-14]). However, over the past two decades or so, there has been an increasing focus amongst mining companies and governments concerning the notion of a "social licence to operate" (SLO) and corporate social responsibility (CSR) in response to impacts on local communities in developing nations.

According to the World Bank [2], SLO is the process through which mining companies engage with communities to acquire free prior and informed consent, negotiate voluntary resettlements and address Indigenous people's rights. In contrast, CSR emerged as a culture of practice through which mining companies attempt to improve livelihoods, socioeconomic well-being and environmental conditions in the regions in which they operate [15]. Indeed, SLO has been seen as an element of CSR which aims to embed a number of critical values, including accountability, credibility and stakeholders' involvement [16].

While early research in mining and development, particularly on CSR, focused on African and Latin American communities (e.g., $[8,17,18]$ ), over the past several decades the approach has also become increasingly common in South East Asia (e.g., [19,20]). While the discourse of CSR has become increasingly common within South East Asia, there has been relatively little research on the subject, particularly in Vietnam (e.g., [15,21,22]) despite the nation having a long history of resource extraction. Moreover, the country has experienced a rapid recent increase in mining activity, largely as a result of rising demand for commodities from China [23,24]. Much of this mining activity is located in remote regions, where mining forms an important part of local livelihoods $[25,26]$. The little research that has been conducted has tended to focus on a narrow set of concerns associated with environmental degradation [27], economic sustainability [28], governance [23] and the impacts of resettlement on local peoples [22]. What is missing is an understanding of the extent to which mining has influenced socioeconomic development in mining communities, particularly when compared to non-resource-intensive locations.

Against this background, the purpose of this paper is to examine differences in the social, economic and environmental conditions of mining and non-mining communities in rural Vietnam in order to understand the extent to which extractive industries contribute to livelihood development, socioeconomic well-being and environmental sustainability. The paper focuses on two case study areas in Quang Nam province that host significant gold mining activities-the districts of Phuoc Son and Phu Ninh.

\section{Mining and Socioeconomic Well-Being at Locality: A Brief Review}

Over the past several decades, researchers have questioned the assumption that resource extraction has provided socioeconomic prosperity to communities [29]. First brought to attention in the 1960s through an investigation into "underdevelopment" in Latin America [30], unequal exchanges in trade was highlighted where raw materials were exported from mining regions at relatively low prices and value-added products were imported at higher value. In response to the mineral extraction boom of the 1980s, Godoy [31] called for the systematic study of the social and cultural dimension of mining and development. According to Ballard and Banks [32], Godoy's review of industry-related research provided a framework that transformed the scope of mining research with a greater focus on mining communities, particularly Indigenous populations in developing countries.

Subsequent research has highlighted the socioeconomic impacts of resource extraction on adjacent communities, particularly in the context of remote regions and ethnic minorities. For instance, the World Bank [2] espoused the benefits of mining-related job creation, infrastructure development and poverty reduction, yet the literature is replete with studies linking resource-dependent communities with high proportions of unemployment and poverty [8,33], tensions between locals and mining companies [34,35] and increased crime [36].

Mining activities have also been criticised as a disruptive economic endeavour causing environmental distress and health impacts [37]. Resource extraction has often been cited as the main 
driver of environmental degradation, particularly with regards to water contamination, deforestation and acid mine drainage [38]. Moreover, due to the use of toxic chemicals in the extraction process, mercury and cyanide have been linked to community-level health impacts $[14,39]$. Globally, volatile commodity prices are an inherent vulnerability of resource-dependent communities. Volatility has been closely associated with fluctuations in mining production and employment [40] and contributes to economic instability. The resulting uncertainty can result in a reluctance of private capital and governments to invest in resource-dependent communities, further constraining economic development [41].

In part, the challenges associated with resource dependence are amplified by the corporate and geographic characteristics of mining operations. In many cases, resource extraction is dominated by a single firm, or a small number of firms, and given the scale and capital requirements of contemporary mining, the sector is often dominated by large multinational companies. Dependence on a single firm has the potential to constrain economic diversification-particularly forward and backward linkages—and increase vulnerability as prices become volatile [42]. Indeed, resource-dependent communities are often frontier locations with large indigenous populations [10] where livelihoods are dependent on mining and where control over company operations is limited [43].

In many respects, much of the debate around "unsustainable mining" aligns with notions of the "resource curse" [44], where economic growth in countries with an abundance of natural resources tends to be lower than in those with fewer natural resources. While evidence of a "resource curse" occurring at national or regional scales is mixed, the underlying causes are complex (see [45]) and there remains an ongoing concern that resource abundance does not necessarily deliver on the promise of higher economic growth and improved social conditions.

Indeed, Hilson and Maconachie [46] point out that the "resource curse" has been blamed for poor economic performance, revenue mismanagement and corruption. Similarly, the Extractive Industries Transparency Initiative (EITI [47]) indicated that the lack of transparency and accountability relating to payments and revenues from mining fuelled conflict and corruption, often resulting in bad governance, political instability and the rise of authoritarian regimes [48,49]. In sub-Sahara Africa, for example, resource wealth has been hoarded by the regimes controlling the regions and systematically depriving local populations of any benefit [46]. As a result, sustainable growth and development in resource-rich developing nations has all but failed [35].

Economics aside, by the 1980s, the rights of locals in mining areas-particularly in respect to culture, land access and livelihoods-started being acknowledged by the international community for two reasons [32]: the emergence of "sustainable development" [50] and the approval of Indigenous people's rights to free, prior and informed consent (FPIC) [51]. The FPIC concept, supported by the International Labour Convention [52] and United Nations Declaration on the Rights of Indigenous People (UNDRIP) [51], was realised as a mechanism for protecting indigenous rights to self-determination [53].

Indeed, FPIC compliance is often seen as a prerequisite for operation at a national level but not a permission to operate by local communities [54,55]. Therefore, in order to garner more support from local residents, corporate social responsibility (CSR) was adopted as a "social licence to operate" [56]. CSR, however, is a contestable concept, even though it was designed to improve environmental and socioeconomic conditions through economic, philanthropic, legal and ethical responsibility [15].

In the mining industry, CSR provides a framework to enhance cooperation between companies and stakeholders [56]. In particular, CSR helps companies balance the diverse demands of communities while protecting the environment and maximising profits [57]. In other words, by employing CSR, mining companies take on more responsibility, including local job creation, human rights protection, welfare enhancement and environmental protection [58]. More importantly, CSR helps ensure acceptance and survival of mining companies within the local context [59], but also the sustainable development of the industry as a whole [60]. 
While CSR discourse is commonplace amongst mining companies and (non)government organisations, it is not without controversy. For example, Manteaw [17] questioned whether CSR simply fulfils a "social licenses to operate" or if initiatives are genuinely aimed at improving the socioeconomic well-being of mining communities. Kapelus [61] also indicated that in order to reduce pressures from mining opponents, companies use CSR as an approach to address the development concerns of local communities.

However, benefits brought to local residents are sometimes inadequate $[62,63]$ and tensions between local communities and mining companies often occur. According to Bebbington, Hinojosa [33] and Bebbington [64], conflicts result from a range of impacts, including land loss, water contaminations, unemployment, noise and dust. Similarly, Banks and Ballard [65] and Kemp et al. [66] identified tensions between mining companies and local residents which result from environmental pollution, loss of local livelihoods, health impacts and social disruption.

For commodity-dependent developing nations, one of the longstanding concerns is that both forward and backward linkages created within the context of mining are often weak [67]. Similar experiences have been noted in Ghana, Tanzania and Mali, where economic development through backward linkages was found to be negligible and the multiplier effects insignificant [8]. This was also found to be true in Angola, Botswana, Ghana and Tanzania, where the breadth of linkage development (forward and backward) was found to be limited at best [68]. Ultimately, however, it is likely that the ways in which resource activity contributes to local economies is contingent on a range of context-specific attributes related to economic structure, remoteness, government policy and even commodity type [40].

Even in the context of developed countries, it has been argued that mining is an unlikely driver of improvements to socioeconomic well-being (e.g., [69-71]). In Blackwell-a community in the Appalachian region of the United States, for example-poverty has been a persistent and pervasive issue even when coal mining was at its peak [72]. Now, decades after the boom, Blackwell's residents have been left with rampant inequality, high levels of unemployment and mine-related illnesses [69,72], an ironic corollary to what has been found in mining communities in the developing nations, including Vietnam.

\section{Research Locations}

Over the last few decades, scholars have identified many of the issues described above in relation to mining in Vietnam. Yet, to date, few comparative analyses have examined differences in environmental impacts and socioeconomic development between mining and non-mining communities (e.g., $[25,26,73])$. In particular, gold mining in Quang Nam province has brought some benefits to the region, however, many developmental and environmental issues can be identified as well. Therefore, an analysis of the advantages and disadvantages of mining for communities in direct contact with the industry compared with those in the surrounding region helps shed light on how mining impacts manifest themselves and are responded to. The research presented in this paper provides a picture of the benefits and challenges facing mining and non-mining communities in Vietnam, with a focus on budgetary contributions, job creation, infrastructure development, unemployment, environmental degradation and social upheaval, in an in-depth comparison of mining impacts.

The research described in this paper was undertaken in Quang Nam province, Vietnam, where the Phuoc Son gold mine, Phuoc Duc commune, Phuoc Son district and the Bong Mieu gold mine, Tam Lanh commune, Phu Ninh district have been operating since the early 2000s. Both are owned by Besra, a Canadian firm operating a number of mines in the region. An in-depth comparison was undertaken between a mining community and non-mining community in each location in order to examine differences in environmental impacts, livelihood development and socioeconomic well-being attributed to the industry. In Phuoc Son district, Phuoc Duc commune (mining) was compared with the immediately adjacent Phuoc Nang commune (non-mining). Similarly, in the Phu Ninh district, Tam Lanh commune (mining) was compared with Tam An commune (non-mining) (Figure 1 and Table 1). 


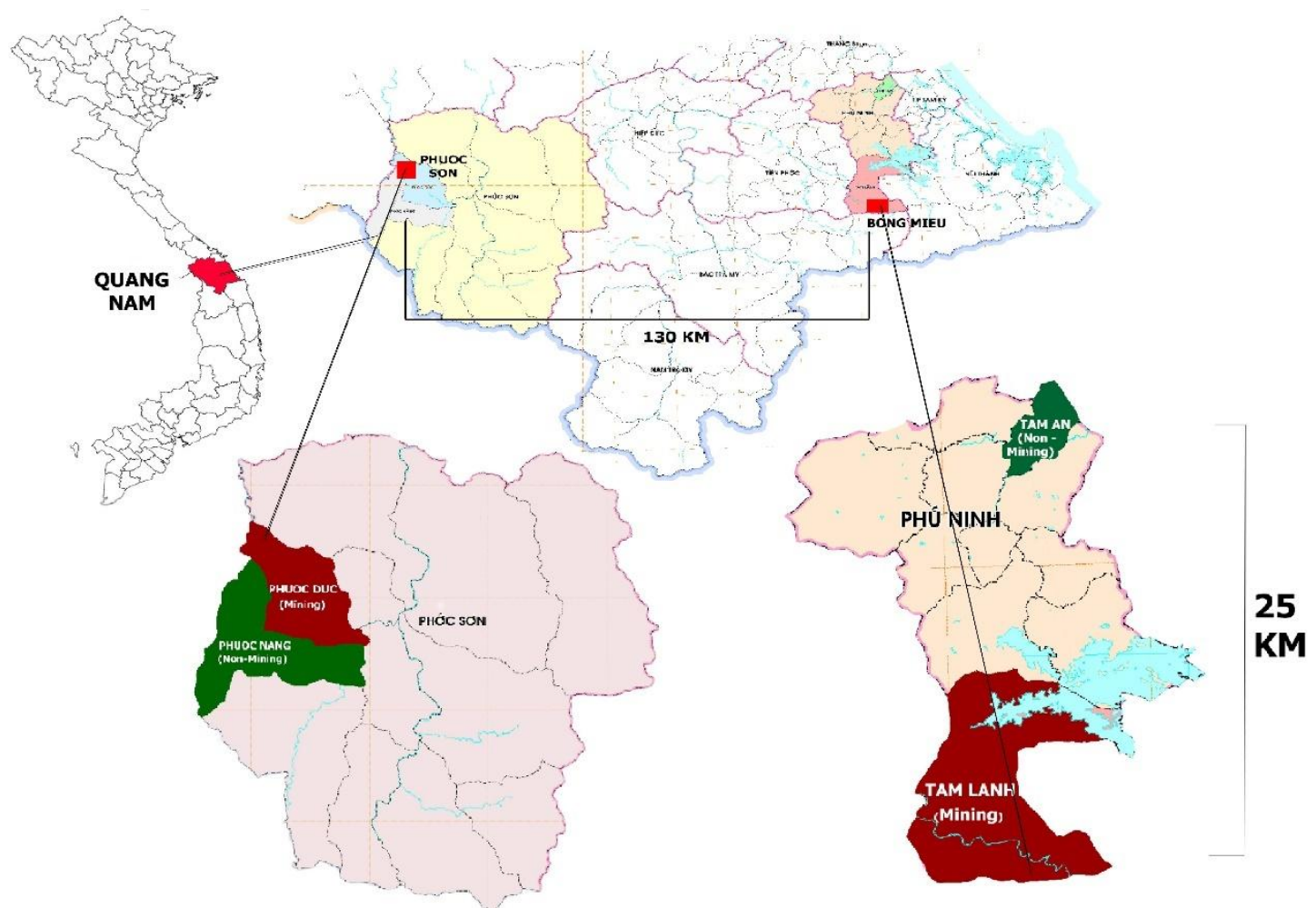

Figure 1. Research locations in Phuoc Son and Phu Ninh districts, Quang Nam province.

Table 1. Summary of geographic and demographic characteristics of Phuoc Duc, Phuoc Nang, Tam Lanh and Tam An communes.

\begin{tabular}{|c|c|c|c|c|}
\hline \multirow{2}{*}{$\begin{array}{c}\text { District } \\
\text { Commune }\end{array}$} & \multicolumn{2}{|c|}{ Phuoc Son } & \multicolumn{2}{|c|}{ Phu Ninh } \\
\hline & Phuoc Duc & Phuoc Nang & Tam Lanh & Tam An \\
\hline Mine & Phuoc Son & \multicolumn{3}{|c|}{ Bong Mieu } \\
\hline Geography & mountainous & mountainous & mountainous & low land \\
\hline Mining & mining & non-mining & mining & non-mining \\
\hline Households & 606 & 550 & 1728 & 1850 \\
\hline Population & 2400 & 2223 & 6708 & 7200 \\
\hline Indigenous People & $>60 \%$ & $>60 \%$ & $0.5 \%$ & none \\
\hline Poverty rate & high & high & low & low \\
\hline Economic sectors & $\begin{array}{l}\text { agriculture } \\
\text { reafforestation } \\
\text { mining }\end{array}$ & $\begin{array}{l}\text { agriculture } \\
\text { reafforestation }\end{array}$ & $\begin{array}{l}\text { agriculture } \\
\text { afforestation } \\
\text { mining }\end{array}$ & agriculture \\
\hline Distance between two communes & \multicolumn{2}{|c|}{ Bordering, divided by mountains } & \multicolumn{2}{|c|}{$25 \mathrm{~km}$} \\
\hline $\begin{array}{l}\text { Distance between commune to the } \\
\text { provincial capital }\end{array}$ & \multicolumn{2}{|c|}{ Approximately $120 \mathrm{~km}$} & $25 \mathrm{~km}$ & $8 \mathrm{~km}$ \\
\hline
\end{tabular}

More specifically, Phuoc Duc and Phuoc Nang communes are found within the remote western reaches of Quang Nam province, central Vietnam and are inhabited by 2400 and 2223 people, respectively (Table 1). The majority of the population in each commune are Indigenous with high rates of poverty. Livelihoods of villagers in each are largely based on agriculture and commercial afforestation. However, mining provides a significant employment opportunity for many males in Phuoc Duc communities. 
Tam Lanh and Tam An are found within the eastern portion of Quang Nam province and are comprised of 6708 and 7200 residents, respectively (Table 1). Tam Lanh lies in the mountainous reaches of the district, with $0.5 \%$ of the population identified as Indigenous and livelihoods comprised primarily of agriculture and mining, with some commercial afforestation. Conversely, Tam An lies in the lowlands of the district, is a non-Indigenous population and livelihoods are focused primarily on agriculture.

Finding a completely suitable corollary to Tam Lanh within the Phu Ninh district was not straightforward. Although the two communities experience different physical geographies, they are similar in demographic makeup and economic diversification. For example, the total population of the two locations as well as proportion of Indigenous population are comparable, and although commercial afforestation is practiced in Tam Lanh, the primary source of livelihoods (aside from mining) is agriculture. Finally, approval to conduct research in the region was influenced by the government approval process and the communities in which they would allow the research to take place.

Licences for both Bong Mieu and Phuoc Son gold mines were granted in 1991 and 1992, respectively [74,75]. Construction of the Bong Mieu mine began in 1997, with a full production capacity of 500 tonnes per day attained in 2006 [76,77]. Similarly, construction of Phuoc Son mine began in 1998 (1953 and 1955 QD/DCKS) with operations beginning in 2003 (2355/GP/2003) and a gold plant commissioned in 2011 with a production capacity of 1000 tonnes per day [78]. It is worth noting that licensing for the mines was provided by central and provincial authorities, and district and commune authorities wield little power in dealing with mining-related issues.

\section{Research Methods}

The methods used for this research were largely based on qualitative techniques. First, a content analysis was employed for obtaining information from a range of sources, including research manuscripts, newspapers, government documents and mining company reports. Examples include feasibility studies for Phuoc Son and Bong Mieu mining projects in 2007 and 2008 [74,75]; the 2014 statistical yearbooks for Quang Nam province, Phu Ninh district and Phuoc Son district; government mining regulations, including 513/2006/TB-UBND, 48/2007/QD-UBND and 207/TB-VPCP/2016; regional development strategies for Quang Nam province, Phu Ninh district and Phuoc Son district; and the 2010 environmental impact assessment reports for Phuoc Son and Bong Mieu mines. In addition, demographic and socioeconomic information for each location was obtained, in part, through government reports and local authority statistics. It should be noted that statistical data more recent than 2014 or for the period prior to 2005 was not available and a concerted effort was made to omit information from multiple sources deemed inconsistent or unreliable.

Second, semi-structured and structured interviews were conducted with individuals and stakeholder groups to collect information from local residents, government officials and mining company employees/managers (Table 2). Interviews took place in person at individual's homes, community common houses, government offices, mining sites, cafés and shops. Interviews lasted approximately 1 hour and primarily occurred in the evenings after work for local community members. In Phuoc Duc and Tam Lanh communes, an assistant was employed for several days to help organise meetings and interviews.

Questionnaires were tailored for the three groups: community members, government employees and mining company employees. Interview topics included mining impacts on water quality and availability, infrastructure, land, education, health care, income, employment, society and the environment. Interviews with mining employees and villagers focused primarily on local impacts on lives and livelihoods, and interviews with government employees and mining management focused on regional issues such as policies used to promote and control mining operations. Participants were identified using a non-probability "key informant" chain sampling approach.

Information obtained from different sources were analysed after a series of cross-checks. For instance, mining-related employment figures were collected from a range of sources, including 
village, commune, district and company reports. Field observations were conducted to triangulate and validate interview data, particularly in regard to infrastructure development, corporate social responsibility initiatives and environmental degradation. Field observations included visiting mine sites, water provision facilities, and health and education facilities as well as visual inspection of roads and rivers surrounding the mines.

Table 2. Number and affiliation of study participants.

\begin{tabular}{|c|c|c|c|c|c|c|c|c|c|c|c|c|c|c|}
\hline & \multicolumn{2}{|c|}{ Phuoc Duc } & \multicolumn{2}{|c|}{$\begin{array}{l}\text { Phuoc } \\
\text { Nang }\end{array}$} & \multicolumn{2}{|c|}{$\begin{array}{l}\text { Tam } \\
\text { Lanh }\end{array}$} & \multicolumn{2}{|c|}{ Tam An } & \multicolumn{2}{|c|}{ District } & \multicolumn{2}{|c|}{ Province } & \multicolumn{2}{|c|}{ Total } \\
\hline & \multicolumn{2}{|c|}{ mining } & \multicolumn{4}{|c|}{ non-miningmining } & \multicolumn{8}{|c|}{ non-mining } \\
\hline & Male (M) & Female (F) & $\mathrm{M}$ & $\mathrm{F}$ & $\mathrm{M}$ & $\mathrm{F}$ & $\mathrm{M}$ & $\mathrm{F}$ & $\mathrm{M}$ & $\mathrm{F}$ & $\mathrm{M}$ & $\mathrm{F}$ & $\mathrm{M}$ & $\mathrm{F}$ \\
\hline Local residents ${ }^{1}$ & 10 & 19 & 21 & 39 & 37 & 14 & 30 & 26 & & & & & 98 & 98 \\
\hline Miners & 14 & & 1 & & 4 & & & & & & & & 19 & 0 \\
\hline Mining management & 1 & & & & & & & & & & 3 & 1 & 4 & 1 \\
\hline NGO (World Vision) & 1 & 1 & & & & & & & & & & & 1 & 1 \\
\hline Gov. Authorities ${ }^{2}$ & 4 & 6 & 10 & 9 & 4 & 5 & 9 & 3 & 17 & 4 & 13 & 1 & 57 & 28 \\
\hline Total & 30 & 26 & 32 & 48 & 45 & 19 & 39 & 29 & 17 & 4 & 16 & 2 & 179 & 128 \\
\hline
\end{tabular}

${ }^{1}$ Local residents representing farmers, fisherman, traders, students, the elderly, housewives and unemployed persons. ${ }^{2}$ Government authorities included the People's Committee and the Departments of Natural Resources, Agriculture, Investment, Planning, Social Affairs, Indigenous and Culture, Education and Health and Infrastructure.

To undertake field data collection, ethics approval was applied for and granted by the University of Western Australia followed by permission from Quang Nam People's Committee. Next, permissions were obtained from each district and commune (case study). The researchers then worked with heads of each village to organise individual and group interviews or organise meeting times directly with government authorities, mining company employees and NGOs.

\section{Results and Discussion}

\subsection{Economic Development}

\subsubsection{Job Creation}

Phuoc Son mine in Phuoc Duc commune, Phuoc Son district has created a number of job opportunities for adjacent communities. In 2013, a company labour report identified that 128 people in Phuoc Duc were employed by the mine, accounting for $15 \%$ of its total labour force. By contrast, the number of employees recruited from the adjacent non-mining community Phuoc Nang was 40, accounting for approximately $5 \%$ of the mine's employees. The proportion of Phuoc Duc households in which a person works for the mine was $21 \%$, whilst the proportion was approximately $7 \%$ in Phuoc Nang. Interviews with community members indicated that these figures are important indicators of poverty reduction, as income of families with persons working for the mine were more secure than those without.

The Bong Mieu mine in Tam Lanh commune, Phu Ninh district has generated a significant number of jobs for local residents. Interviews with district authorities and mining staff indicated that approximately 300-450 residents from Tam Lanh were recruited to work in the mine between 2010 and 2013, accounting for approximately $40 \%$ of the labour force. However, this number is likely lower according to a report by the provincial Department of Natural Resource and Environment (DNRE) in 2014 (no number 14/08/2014), showing that only 59 people in Tam Lanh had actually been recruited to work in the mine ( $14 \%$ of the labour force).

In contrast, interviews and statistical reports for Tam An indicated that, in 2014, no residents were employed in the mine and only a few businesses were supported by mining activities. Based on a provincial DNRE report (2014), 111 employees were recruited from communes within Phu Ninh district (excluding Tam Lanh). The distance from Tam An to Bong Mieu mine is approximately $25 \mathrm{~km}$, 
whilst other communes are located closer and would be expected to have a greater portion of their labour force employed in the mine. This provides an indication of the mine's geographic sphere of influence.

\subsubsection{Poverty Reduction}

Based on commune and district statistical accounts, poverty rates in Phuoc Duc fluctuated between 2005 and 2009 and were below those of Phuoc Nang in the period between 2010 and 2014 (Figure 2). Poverty was measured based on monthly or annual income, as defined by the government for each time point [26], which may partially, but not entirely, account for fluctuations in the poverty rate. In 2006 and 2010, government decision No 170/2005/QĐ-TTg was applied, classifying families as "poor" if their income was less than VND 200,000 and VND 260,000 per person per month, respectively. In 2011 and 2015, decision No 09/2011/QĐ-TTg was applied, classifying families as "poor" if their income was less than VND 400,000 and VND 500,000 per person per month, respectively.

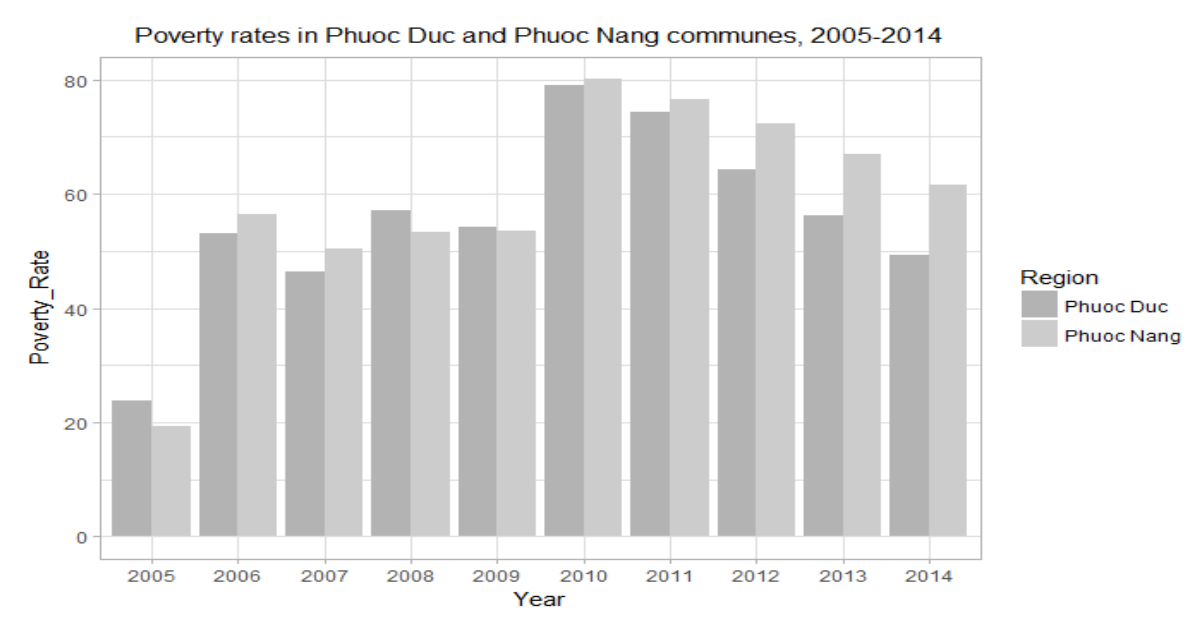

Figure 2. Poverty rates for Phuoc Duc and Phuoc Nang communes, 2005-2014 [78].

During the period from 2005 to 2009, poverty rates in Phuoc Duc were higher than Phuoc Nang, except for the years 2006 and 2007. In 2010, the poverty rates of Phuoc Duc and Phuoc Nang were $79 \%$ and $80 \%$, respectively, and whilst both communes experienced a reduction in residents living below the poverty line, by 2014, Phuoc Nang's poverty rate was 12 percentage points higher than that of Phuoc Duc. Whilst it is difficult to infer a causal relationship, there is an indication that employment in the mine may have contributed to these differences. More specifically, one women interviewee identified that "her husband's salary from working for the mine is regular and stable which is important for their family". This was also highlighted by an interviewee from the Phuoc Duc authority, who stated that "income from people working for the mine has been a key driver in reducing the commune's poverty rate". In recognition of the World Bank's reasoning that mining contributes to job creation and income generation in rural communities [79], the Phuoc Duc example indicates that mining may have contributed to poverty reduction.

Poverty rates in Tam Lanh commune (mining) were higher than those of Tam An commune (non-mining) between 2010 and 2013 (Figure 3). The difference in poverty rates between the communities decreased considerably during this period and, by 2014, the poverty rate in Tam Lanh had reduced to a point lower than that of Tam An, and mining may have been an important factor. Local miners in Tam Lanh confirmed that employment in the mine was important for their families and had generated stable incomes. In addition, a small retailer in the region stated that "trade had increased largely based on the increase in mining jobs". Similarly, one retired government employee stated that "local miners' income is quite good and has helped decrease poverty in the commune". 


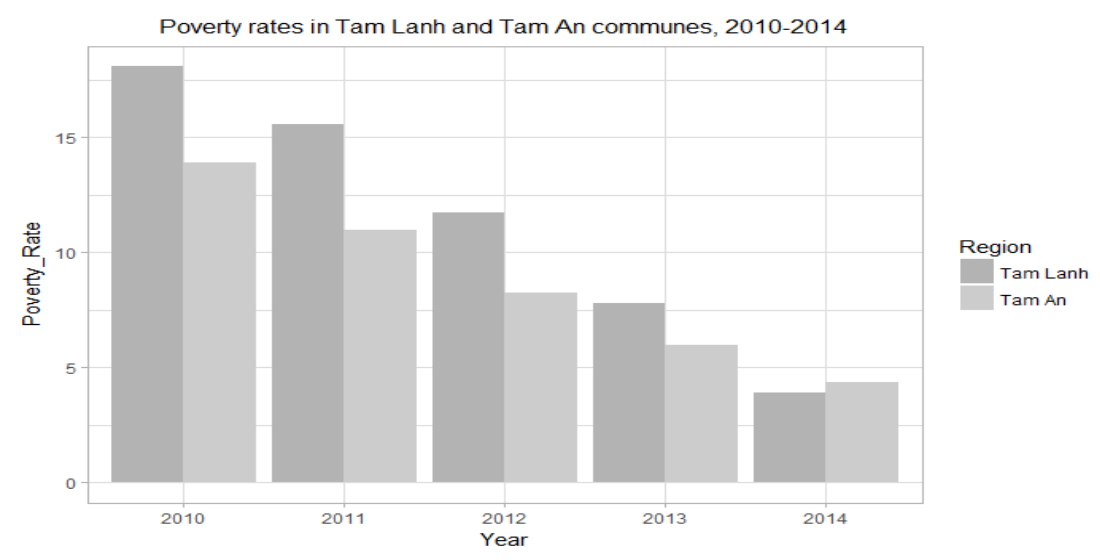

Figure 3. Poverty rates for Tam Lanh and Tam An communes, 2010-2014 [80].

Mining operations in Phuoc Son have created some opportunities for local economic growth. Interviewees indicated that the gold-processing plants have resulted in the establishment of a number of services suppling production, including hotels, petrol stations, transport firms and food suppliers (i.e., backward linkages). In addition, 6666, a privately-owned company, has been permitted to collect gold and lead in mine tailings, which provides additional economic development opportunities for the local community.

\subsubsection{Infrastructure Development}

Phuoc Duc has also benefited from infrastructure development as a result of mining. A $10 \mathrm{~km}$ road connecting the National Highway to the gold plant has been constructed by the mining company along with upgrades to two bridges. As the road network provides the backbone of infrastructure in the region, its development has resulted in improved accessibility, facilitating increased trade and labour mobility. One local interviewee highlighted that "due to the upgrade to roads and bridges, trucks can access farms to purchase forest products and this has increased prices." Of note is that while the construction of this infrastructure was primarily for the benefit of the mine, it has broader benefits for other sectors such as agriculture.

In contrast, infrastructure development in Phuoc Nang has largely depended on budget allocations from provincial and district governments. Statistics indicate that, on average, the total budget allocated for development in Phuoc Nang was approximately VND 2-2.5 billion (estimated USD 100,000-125,000) per year between 2010 and 2014. Budget allocations over the last several years have resulted in the paving of $72 \%(4.4 \mathrm{~km})$ of roads connecting villages, $84 \%(0.65 \mathrm{~km})$ of village internal paths and $50 \%(8 \mathrm{~km})$ of roads to fields. Interviewees highlighted that what has been paved is a result of an ambitious "new rural" programme put forth by the government, which draws on contributions from local residents. The 2014 report on the "new rural" programme (no number, September 2014) indicated that local resident's contribution accounted for $1 \%$ of total expenditures, with Phuoc Nang commune government contributing nothing.

Development of infrastructure by the mining company has benefited villagers in Tam Lanh. For example, in 1992, 16 kilometres of sealed roads were built from the main road to the mine. In 2006, 5 kilometres of roads were built to connect Village 5 to the mine, and in 2012 a $3 \mathrm{~km}$ road from Village 6 to Que Phuong Bridge was paved. These roads, constructed by the mining company, have provided great advantages for local people, increasing trade and promoting economic growth. Furthermore, contributions to the commune's infrastructure budget have reduced financial burdens on the district government of Phu Ninh.

In contrast, infrastructure development in Tam An has not benefited from the mining company, as Tam An largely relies on allocations from the provincial and district governments. Interviewees indicated that the total budget allocated for development in Tam An was approximately VND 
1.5 billion (USD 75,000) in 2010 but increased to approximately VND 4 billion (USD 200,000) between 2012 and 2014. Whilst these amounts were for substantial development investments (i.e., roads, irrigation, community houses, health clinics, schools and markets), field observations and a report from the commune (130/BC-UBND/03-12-2014) showed that 78\% (14 km) of the village was connected by roads and $96 \%(16 \mathrm{~km})$ of village paths and $73 \%(8 \mathrm{~km})$ of roads to fields were being paved. These findings were the result of the "new rural" programme put forth by the Phu Ninh authority (6166/QD-UBND/29/11/2011) using volunteered local labour and building materials supplied by the authorities.

\subsubsection{Tax Revenue}

In Phuoc Duc, local government budgets have also received a positive contribution from mining activities. Specifically, environmental and natural resource taxes provide substantial revenue for local governments. Interviewees indicated that, in 2012 and 2013, these taxes accounted for approximately $14 \%$ and $43 \%$ of total revenue for the commune. As identified by a Phuoc Duc commune staff member, "tax contributions from the mine are crucial for socio-economic growth".

On the contrary, revenue in Phuoc Nang depended heavily on district allocations. Interviewees indicated that there were no businesses in Phuoc Nang, so the commune receives nothing in revenue. Every year, Phuoc Nang has to submit a budget with estimates for next year's expenditures, however, approval of the plan is uncertain, which constrains forward planning.

In Tam Lanh, local authorities confirmed that "taxes from the mining company are important revenue for socio-economic development." For example, natural resource taxes and fees paid for environmental protection were reported as important revenue. These taxes were paid directly to the provincial government and proportioned to the districts and communes in accordance with decisions 32/2010/QN-UBND and 31/2013/QD-UBND. Interviewees and financial figures indicated that, between 2012 and 2013, these taxes accounted for $26 \%$ and $20 \%$ of the commune's total revenue, respectively.

By contrast, Tam An commune had not been the beneficiary of financial contributions from resource extraction activities. Budget allocations from the district government were not enough to cover expenditures, with a 2014 commune report citing revenues to the commune at approximately VND 3 billion (USD 150,000), while total expenditures were approximately VND 8 billion (USD 400,000). The commune depended on VND 5 billion (USD 250,000) from the district government to cover regular expenditures.

Benefits from mining operations in Phuoc Duc commune have helped the surrounding regions. Investment in roads and bridges have helped Phuoc Son district in general, as these improvements have reduced the government's budget burden. Interviews with district employees indicated that the budget for development investment in Phuoc Son in 2013 was approximately VND 105 billion (USD 4.7 million) for 12 communes. It could be argued that direct investment from the mining company in Phuoc Duc may have allowed the rerouting of budgets allocated by the regional government to other communes.

\subsubsection{Economic Activity}

Similar to Phuoc Duc, Tam Lanh's economy has benefited from forward and backward linkages. However, these linkages have resulted in a number of issues, including debts to service providers, pollution and job loss when the mine is closed. By contrast, Tam An's economy did not receive such benefits, but local families were active in economic diversification. Statistics for Tam An indicated that whilst one village had 197 households receiving the majority of income from agriculture, $34 \%$ had at least one person working as a brick layer, brick layer's assistant, household worker, babysitter or carpenter. This diversification had increased opportunities for people in Tam An and has helped mitigate shocks that are highly dependent upon the mining sector. 
Contributions from mining revenue have created an "additive economy" in Phuoc Duc commune. Due to a large tax debt (207/TB-VPCP/2016), mining operations in Phuoc Son (and Bong Mieu) were stopped by the Quang Nam Tax Department [81]. This closure resulted in financial issues for Phuoc Duc. Interviews indicated that in 2012 and 2013, for instance, environmental fees for Phuoc Duc were approximately VND 1 billion (USD 500,000) and VND 5 billion (USD 250,000). When mining operations were stopped in July of 2014, environmental fees dropped to approximately VND 0.3 billion (USD 15,000) and by 2015 income was zero. In addition, a representative of the Phuoc Duc authority stated that "development investment has been impacted recently due to a substantial drop in tax contributions (only 3\%) in 2014".

\subsection{Social Implications}

\subsubsection{Corporate Social Responsibility (CSR)}

Whilst Phuoc Nang has not directly benefited from CSR initiatives, CSR projects have focused on development in Phuoc Duc (Table A1). Authorities' indicated that in 2012 and 2013, "the company" supported approximately USD 21,400 in upgrades to the local water system for irrigation and repaired and upgraded equipment for the Community House in Village 4. In addition, in collaboration with the East Meets West Foundation, a clean drinking water project valued at USD 200,000 provided potable water to more than 300 households adjacent to the mine. The company also provided supplies for the library, computers for the local secondary school and meeting tables and chairs for patients at the local clinic.

Similarly, a number of direct benefits from CSR initiatives were reported for Tam Lanh commune (Table A2). As confirmed by interviewees, company accounts showed that between 2006 and 2012, approximately VND 12 billion (USD 600,000) was spent on such activities. Aside from infrastructure development, CSR initiatives included individual household repair, direct household support, contributions to education and health care and agricultural investment. Interviews indicated that VND 360 million (USD 180,000) was donated to support animal husbandry and VND 300 million (USD 150,000) to build a kindergarten. In collaboration with the NGO World Vision, a water treatment plant was built in 2007 providing clean drinking water to over 451 families in Villages 8, 9 and 10.

\subsubsection{Conflicts}

Despite CSR investment, tensions between local residents in Phuoc Duc and the mine, particularly Village 4, still exist. According to villagers, conflicts have arisen from waste water discharge in the local river, mine related dust, restricted employment opportunities and poor mine management. Consequently, protests by local residents blocked buses delivering workers to the mine. More specifically, from July 2011 to July 2014, there were four protests where company buses were blocked, with the most serious in May of 2013, resulting in a 5-day work stoppage. The protesters blocked access to and from the mine and the company had to hire a helicopter to transport food, water and essential items for miners inside the blockade. It should be noted that there was no violence against the miners and these conflicts were dealt with peacefully and without injury or police involvement.

Similar to Phuoc Son mine, tension between Bong Mieu mine and Tam Lanh residents is an ongoing challenge. The most serious incident occurred in August 2010 when several thousand residents blocked access roads to the mine, protesting the transportation of quarried material from Phuoc Son to Bong Mieu for processing. Residents argued that "quarried materials have to be processed at the location of extraction". "We do not accept the transport of quarried material to other places because it will create additional pollution" one interviewee responded. The conflict lasted 2 days and resulted in a number of injuries. Again in 2005, tensions between local residents and company security led to a night-time attack on company assets by 500 individuals. The group destroyed property valued at USD 200,000 and stole raw quarry materials and other valuable items. Several people were caught, and one person was sentenced to 2 years in prison. 
In the context of Phuoc Son, although some economic growth has resulted from mining activities, development of forward and backward linkages has actually burdened local communities. For instance, 6666 has been blamed for creating additional pollution and, as one interviewee highlighted, "the 6666 company has discharged waste water without treatment, but we do not have evidence for this". In addition, local service providers (LSPs)—including food retailers, hotels, fuel distributors and transport enterprises-have charged the company with withholding payments. Local papers have reported that food providers and transport companies were owed up to VND 220 million (USD 10,000) and VND 20 billion (USD 1 million), respectively [82]. These debts have impacted livelihoods and fuelled local retaliations (e.g., on December 2013, hundreds of subcontractors destroyed Phuoc Son's mine gate and requested payment).

\subsubsection{Unemployment}

An extended period of closure of the Phuoc Son mine also occurred from July 2014 to August 2016, proving difficult for employees and their families in both Phuoc Duc and Phuoc Nang $[81,83]$. As mentioned previously, due to tax debt, the mining company's operations were suspended at Phuoc Son, resulting in hundreds of layoffs. In the interim, local miners had to seek alternative livelihoods, including fishing, farming and freelance work. Some took to artisan mining and illegal logging, resulting in further environmental degradation. Due to dependencies on the mine, interviewees in Phuoc Duc indicated that livelihoods were unstable, and they preferred to work for the company when production resumed. One woman stated that "she wants the company's production to resume so her husband can continue working". The closure adversely affected income but it is unclear the extent to which poverty rates were influenced in Phuoc Duc, as 2015/2016 figures had not been released at time this manuscript was written. However, a commune staff member stated that "the poverty rate in Phuoc Duc is likely to be alarming". It should be noted that during the mine's closure, Phuoc Duc was significantly affected in comparison to Phuoc Nang, as three times as many residents were employed in the mine.

One of the greatest problems facing Phuoc Nang commune (non-mining) is unemployment. Interviewees indicated that women had no work for up to 10 days per month and men were without work for 3-7 days. During unemployment periods, they often looked for short-term fixes, however, in Phuoc Nang more than $60 \%$ of households were identified as poor and demand for labour locally is limited. It should be noted that unemployment is a problem for the whole Phuoc Nang community, not just the miners laid off by the company.

Indeed, unemployment was also a problem in Phuoc Duc, but not as problematic as in Phuoc Nang. In Phuoc Duc, only those livelihoods dependent on collecting rocks to extract gold were concerned with unemployment, as these activities were not allowed on the mines lease during stoppages. In contrast, the majority of those interviewed in Phuoc Duc did not complain of unemployment.

High unemployment in Phuoc Nang, particularly men, may have had an impact on the conservation of surrounding natural resources and exacerbated socioeconomic issues. Women interviewees indicated that, among unemployed men, only a small proportion agreed to look for work or participate in household activities, with the majority interested in hunting and drinking. During conversations with one group of women (15), a group of intoxicated young men (5) tried to interfere in the discussion. Similarly, the village head in Phuoc Nang was found to be intoxicated during a meeting at the commune office ( 2 p.m.) and another village head could not take part in a morning interview due to stomach pains from the previous nights' drinking.

An additional consequence of drinking is family violence. Although this was not identified as a serious issue in Phuoc Nang, during one interview, a deputy chairwoman identified that the Phuoc Nang Women's Association was instrumental in reducing family violence and spousal separations, particularly in Village 1.

Unemployment during mine closures has also caused problems for communities in Tam Lanh. Similar to Bong Mieu mine, tax debt resulted in the suspension of production for 6 months in 2014 
and 3 months in 2015. In accordance with notice 156/TB-UBND/05-05-2017 of QNPC, the company's licence had not been extended past March 2016, and there are questions concerning the mines' future viability. These closures have resulted in work interruption for local miners, requiring employees to seek alternative livelihoods. During closures (and similar to Phuoc Duc), some locals engage in artisan mining and illegal logging, however, income generated from these activities was deemed unstable, and employees sought re-employment in the mine when operations commenced. Field observations identified that mine closures in Tam Lanh did not affect unemployment in Tam An. In fact, according to labour reports for 2013 and 2014, the proportion of people regularly working in Tam An was 90\% and $92 \%$, respectively.

However, outmigration was high in Tam An, as statistics indicated that, in 2013 and 2014, approximately 600 people (or $14 \%$ of the labour force) had immigrated to other districts for work. Many people in Tam An, especially young married men, migrate seasonally for work in other regions. Remittances therefore helped Tam An households through income accumulation, providing access to quality seed, enhancing social and economic networks and increasing knowledge transfer of farming practices.

One of the biggest problems in Tam An was that people, particularly young single men, were not interested in farming. Interviewees highlighted that working in agriculture was difficult and resulted in low income. As socioeconomic development has created more pressures on young people to enjoy life, without economic mobility, agriculture was seen as a poor option. Therefore, young people without vocational or university education preferred to leave their villages to look for outside opportunities. Interviewees indicated that even experienced farmers did not want to work in agriculture due to perceived impacts on health and limited economic opportunity. This sentiment may explain why there is considerable outmigration in Tam An.

\subsubsection{Antisocial Behaviour}

In terms of antisocial behaviours and their consequences, district statistical accounts indicated that drug addiction and HIV infection were a problem, but more so in Phuoc Duc than in Phuoc Nang [84]. For instance, in Phuoc Duc, the number of heroin addicts and HIV infections managed by authorities were 7 and 21, respectively. These are high numbers given the geographic isolation of Phuoc Duc. On the contrary, no drug addiction was reported in Phuoc Nang and the number of people testing positive for HIV was six. Indeed, interviewees blamed mining activities for attracting drug dealers to the area, with a view that this in turn fuelled drug addiction. Similarly, community members felt that as a result of increased immigration to the area and the antisocial behaviour that accompanied mining activities, HIV infections had increased.

In Tam Lanh, safety and crime were raised as a concern. Interviewees identified that the number of young people addicted to heroin has risen to over 50 in Tam Lanh alone. At a recent village meeting, it was reported that 19 villagers had tested positive for heroin use, and the perception was that the problem is attributed to mining [85]. In addition, gaming has been increasingly reported as a problem. Indeed, field observations during this research revealed young men playing cards during working hours in local cafés as a reasonably widespread activity. Interviewees indicated that stealing and fighting had increased in the region, and blamed mining for the situation.

In Tam An, interviews and field observations revealed that drug addiction (two cases) and HIV infection (one case) were not a problem. In addition, reports from the police office showed that the commune had limited concerns regarding crimes or drug dealing, and most interviewees were grateful for the safety situation in their communities. 


\subsection{Environmental Effects}

\subsubsection{Pollution and Health}

The biggest distress to the environment in Phuoc Duc was water pollution, as interviewees felt that rivers and aquifers had been contaminated by mining activities [85]. Interviewees and environmental reports indicated that Daksa — the main river in the region-has been heavily polluted, and mining activities were blamed for contamination. According to a more recent Environmental Impact Assessment (EIA) report [86], $137 \mathrm{~m}^{3}$ of water per day was used during the gold fraction stage $\left(5.73 \mathrm{~m}^{3}\right.$ per hour), with wastewater containing a cyanide concentration of 1000-2000 mg per litre, along with other heavy metals. Moreover, residual tailings of $5043 \mathrm{~m}^{3}$ per year containing cyanide were being produced on site. Causing significant concern is the plants upstream location, as discharge has been blamed for health issues downstream [86].

Similarly, water pollution was also one of the biggest concerns in Tam Lanh commune [85]. The Bong Mieu River, the largest in the region, has been heavily polluted by mining operations. One interviewee living along the river for several decades identified that the river used to be a good place for fishing and swimming and supported agricultural practices, however, in the last decade it had earned the moniker "dead river".

According to an EIA report, processed waste water was discharged into the river at an average rate of $2151 \mathrm{~m}^{3}$ per day, of which $24 \mathrm{~m}^{3}$ contained cyanide at a concentration of 3-5 mg per litre. From an environmental perspective, treated and untreated waste water was being discharged directly into the river upstream of communities that rely on the river for agricultural production. In addition, air quality was a concern in Tam Lanh, particularly odours, dust and noise. A number of interviewees highlighted that irritating smells were frequently discharged from the Bong Mieu gold plant (usually after 10 p.m.) and, according to EIA reports, $138,200 \mathrm{~kg}$ of explosives are used annually. This generates dust, noise and a number of dangerous gases such as $\mathrm{CO}_{2}, \mathrm{CO}, \mathrm{SO}_{2}, \mathrm{NO}$ and $\mathrm{NO}_{2}$. Finally, mining-related traffic on local roads often exceeds the national noise standard of 3-8 $\mathrm{dB}(\mathrm{A})$. With the majority of households located along main roads, home life is often disrupted during daytime hours.

Consequently, health impacts are a significant concern in Phuoc Duc particularly from contaminated drinking water [85]. Interviewees identified that "local people are concerned and angry with the company. Pollution has permeated the soil and rain water brings pollution into the river." Indeed, many people in the mining villages have witnessed health impacts, resulting in death in some instances. For example, due to contact with contaminated river water, dermatological and gynaecological issues have been cited by locals. In addition, it was identified by interviewees that 10 cows had died after drinking water from the river and, after a recent flood event, both banks of the stream were covered with tailings, destroying rice crops.

Likewise, local residents in Tam Lanh commune were concerned about health impacts [85]. Interviewees indicated that in 2003 they were using water from the Bong Mieu River for animal husbandry, but during field visits in October 2015, community members had stopped using water from the river for irrigation and watering of livestock. For mining adjacent communities such as Villages 8 , 9 and 10, residents no longer drank water from wells due to contamination and several interviewees blamed the recent rise in morbidity on mine-related pollution.

In Tam Lanh, local people were most recently concerned with the 60 tons of cyanide bought by the mining company for gold production. Due to mismanagement, it was identified that the cyanide was counterfeit (15.012.01-GDTM/N2 and 15.013.01-GDTM/N2) and not stored appropriately, causing the local authorities to be contacted. Interviewees indicated that local people were concerned with the lack of transparency, but also the haphazard approach to dealing with chemicals. For instance, the company suggested that 20 tons of the counterfeit cyanide could be used in local construction while the remaining cyanide could remain in company stores for later use (464-15/BGM-PSGC), a suggestion ultimately rejected by the authorities. 
In Phuoc Nang, although drinking water was not as contaminated as in Phuoc Duc, water quality was a concern for interviewees. People in Village 3,4 and 5 using streams from nearby mountains complained that agricultural practices upstream were polluting water downstream. However, this issue did not seem to be mine-related, and other interviewees identified that the water quality in the mountains was still good. By contrast, people in Village 1 and 2 who used water from wells expressed concerned that the water smelled. In addition, Villages 1 and 2 had limited alternative water sources.

In Tam An, drinking water was not a concern and authorities had a feasible plan to connect households who lived along the DT 615 road and the national highway to a drinking water system in Tam Ky city. However, soil and surface water in the region might be polluted by intensifying use of insecticides and herbicides in the last few decades, though this is only speculation. Field observations identified that, although the Tam An authority had a program for collecting used insecticide and herbicide containers, locals were still concerned with soil and water contamination. Indeed, local people understood the hazardous nature of these chemicals, but in the context of rural life, economic gain through agriculture is paramount to sustaining livelihoods.

\subsubsection{Land Allocation and Conservation}

The ability of the mining company to manage its leases has been a concern of community members and local government officials. Steven and Fulton [75] reported that the mining company was granted exploration rights (1953 and 1955 QD/DCKS) in 1998 by the Ministry of Industry for $100 \mathrm{~km}^{2}$ of forested land in Phuoc Duc. In 2003, a second licence (2355/GP) was granted by the Ministry of Planning and Investment, decreasing land available for exploitation to $70 \mathrm{~km}^{2}$, and, in 2008, this area was further reduced by the Ministry of Natural Resources to $42 \mathrm{~km}^{2}$ (07/GT-BTNMT). The reason for reducing the company's lease, as identified by interviewees, was a perceived inability to manage these lands, which had been impacted by conversion to agriculture, illegal logging and artisanal mining.

In Tam Lanh, a slightly different trajectory has occurred. Based on a 1991 licence (140/GP), 3000 hectares were granted for company operations, and by 1992 (582/CNNg-KTM), another 358 hectares were released for exploration. By June 2006, notice 513/TB-UBND issued by the Quang Nam People's Committee (QNPC) approved exploration within forested lands set aside for protection (blocks 590 and 591) and, as a result, 2282 hectares of protected forests were opened for production (48/2007/QD-UBND). Finally, in 2008 (2125/GP-BTNMT), an additional 26.3 hectares were added to the company's lease.

Similar to Phuoc Duc, however, interviewees argued that the land allocated to the mining company was too large for the mine to manage. One interviewee suggested that "it may not be the right decisions to allocate a very large area of forested land to the mining company whilst it does not have the capability to limit exploitation and manage the land. This has created pressures on local authorities regarding forest protection." Indeed, the protection and management of forests have been charged as ineffective and have resulted in clearing for agriculture, artisanal mining and illegal logging.

As for non-mining communities, one of the biggest environmental concerns was resource exhaustion. Interviewees in Phuoc Nang identified three key issues: limited arable land, poor quality of adjacent forests from extensive clearing in the late 1970s and early 1980s and wildlife depletion from overfishing and trapping. Through the interview process, it was identified that limited agricultural land existed for young couples recently married or separated from their parents. In addition, the clear cutting of several thousand hectares of Song Thanh Natural Reserve and allocation of portions of the Reserve for production may exacerbate a precarious environmental situation.

In Tam An, residents were also concerned with soil degradation. Some areas of arable land along the Suoi Can stream in An My were covered by sand after recent flooding and could not be cultivated. Fertile agricultural soil had been eroded by flooding, degrading the landscape and reducing soil quality. Weather extremes, flooding and inappropriate human activities have exacerbated soil management in Tam An. 


\section{Conclusions}

Overall, the findings presented in this paper suggest that mining has contributed to more economic development opportunities in Phuoc Duc and Tam Lanh communes than in non-mining regions (Phuoc Nang and Tam An). However, extractive operations have also been acknowledged as key drivers of environmental degradation and social upheaval. In both mining locations, tensions between local residents and the "company" are omnipresent. Although the "company" has endeavoured to support local communities, it is apparent that they have failed to sway popular opinion, with distrust and animosity over water contamination, air pollution, unemployment, health impacts and livelihood uncertainty pervasive.

Unfortunately, CSR initiatives have not been perceived as meeting community expectations of "social responsibility", which supports a growing body of literature calling for alternative approaches to fostering local support for mining activities [58-60]. In the communities we examined, CSR initiatives were not deemed as sufficient by the local communities due to perceptions of uneven benefit sharing. However, expectations from local communities may not be realistic and, as [36] have found, local residents often feel a need to be patronised. When patronisation does not meet expectations, local communities can "find themselves betrayed, cast aside and disconnected from the processes of development and modernity" [87]. According to ILO [52], the World Bank (2005) and the UN [51], consistent consultation with local communities can help alleviate some of these tensions, but in the case of Phuoc Duc and Tam Lanh, consultation between local residents and the mining company were limited at best and, when they did occur, were found to be ineffective (04/11-01-2010, 02/11-01-2010, 366/CV-UBND/30-11-2009).

Mining-related economic development and diversification in Phuoc Duc and Tam Lanh was also perceived as inadequate, contributing to malaise for the mining company. According to Robbins ([88], p.166), "mining companies can often be resistant to deepening their engagement with local or national economic processes beyond the bare minimum." Within the context of this research, it was found that tax payments from mining operations in Phuoc Duc and Tam Lanh were perceived as having a significant benefit in promoting community development. However, local service providers, government departments and residents alike became reliant on commerce, tax receipts and employment opportunities. Resource dependence can become apparent when mine closures occur and money stops flowing.

For non-mining communities (Phuoc Nang and Tam An), benefits from mining were not direct, but some spillover was identified. Ironically, because there was less reliance on mining to support livelihoods, one could argue that these communities were better off, particularly in Tam An (but not without mining related environmental impacts). In fact, Phuoc Nang and Tam An benefitted from some increased economic activity, however, because mining was not the primary economic driver, livelihoods remained diversified, mitigating economic shocks such as a mine closure. Junod et al. [89] refer to this region as the "Goldilocks Zone" where, in this example, Phuoc Nang and Tam An (non-mining regions) were close enough to obtain benefit from economic spillover, but far enough away to avoid substantially negative environmental and social impacts.

More recently, a complicated mix of tax debt, local discontent and failed negotiations between Besra and government stakeholders (207/TB-VPCP/29/07/2016) resulted in the shutdown of production at both Bong Mieu and Phuoc Son by the Quang Nam authorities (18 July 2014 and 22 July 2014, respectively). The mining company has complained that these actions were illegal and a direct result of coercive measures conducted by the provincial Quang Nam Tax Department [81]. After 2 years of suspension, the Phuoc Son mine was permitted to reopen on 17 August 2016 [83], however, by 1 September 2016, Quang Nam People's Committee informed the mining company that they would not support the reinstatement of their operating licence (document 4227/UBND-KTN). On 19 July 2016, the Ministry of Natural Resource and Environment requested Bong Mieu mine stop operations completely (2910/BTNMT-DCKS) and, on 30 June 2017, Besra announced that it had completely divested from all interests in Vietnam [90]. 
Although Besra's mining operations have ceased and the company has completely divested from Vietnam [90], the negative impacts on the community and the region as a whole will live on. Interestingly, even with local sentiments of malaise, interviewees commenting on the recent mine closures indicated that "it is good for the commune if the company recommences its operations." Some local commune staff also argued that, without the mining company, it was impossible for mining authorities to manage artisanal mining. However, in the context of Phuoc Duc and Tam Lanh, while economic development may be perceived as positive, social concerns, tension between locals and the company and environmental degradation may usurp positive sentiment.

This mirrors findings from Africa-where mining has supported economic growth-but local welfare has seen little improvement [8]. In fact, mining has been seen to increase inequality in some cases [5], but when poverty reduction does occur, it may be much slower than in non-mining regions, or the rest of the developing world, for that matter [8,91]. In fact, while mining is still considered a major driver of growth, the distribution of social and economic benefits is often concentrated in cities rather than in the regions from which the resources were extracted [66,92].

In Phuoc Duc and Tam Lanh, mining contributions to the local economy and social setting has been mixed, with the real beneficiaries being the provincial and district governments. Tax receipts bolstered local coffers when the mines were in operation, and district government representatives identified that the company helped manage artisanal mining and illegal logging on their lease. Ironically, local community members did not communicate the same sentiment, citing mismanagement and exploitation of leased lands by the company.

In conclusion, relations between mining companies and local residents are complicated, nuanced and context specific. However, the role of mining companies in promoting long-term socioeconomic development needs to be re-examined, specifically in association with promoting well-being and the needs of local communities. Transparency of operations and direct consultation with local people needs to be enhanced overall, and the benefit of mining in a particular location should be independently reviewed before operations commence. Findings from initial environmental assessments can provide fundamental baselines and pave the way for evidence-based strategies to enhance development and promote a positive experience for both local communities and the mining industry as a whole.

Author Contributions: Nhi Ba Nguyen, Bryan Boruff and Matthew Tonts collectively designed the field study approach; Nhi Ba Nguyen collected information in the field, analysed the data and wrote the first draft of the manuscript. Bryan Boruff and Matthew Tonts provided editorial assistance on subsequent drafts of the manuscript including revisions.

Acknowledgments: The authors would like to thank the three reviewers and journal editor for their insightful feedback which has strengthened the paper. This project was supported by an Australian Government Endeavour Scholarship.

Conflicts of Interest: The authors declare no conflict of interest.

\section{Appendix A}

Table A1. Key corporate social responsibility (CSR) initiatives in Phuoc Duc commune (source: interviews and [93]).

\begin{tabular}{|c|c|c|c|}
\hline CSR Activities & Year & VND (Million) & USD (Estimation) \\
\hline Repairing the Community House in Village 4 & 2012 & 100 & 4700 \\
\hline Upgrading the scheme water system for irrigation & 2012 & 260 & 12,000 \\
\hline Clean water project for Villages 1, 2, 3 and 4 & 2012 & 4500 & 200,000 \\
\hline Toilets for Village 4 & 2012 & 69 & 3000 \\
\hline Equipment for Community Houses (chairs, tables, loudspeaker and amplifier) & 2013 & 100 & 4700 \\
\hline $\begin{array}{l}\text { Support to local socioeconomic programs and community assistance program. } \\
\text { E.g. roads, additional classroom construction, housing construction, educational } \\
\text { and health care support for the poor. }\end{array}$ & Up to 2015 & 10,000 & 470,000 \\
\hline
\end{tabular}


Table A2. Examples of key CSR initiatives in Tam Lanh, 2006-2014 (Source: interviews).

\begin{tabular}{|c|c|c|c|}
\hline CSR Activities & Year & VND (Million) & USD (Estimation) \\
\hline Providing a clean water system for 451 households of Villages 8, 9, 10 & $2006-2008$ & 1000 & 62,000 \\
\hline Supporting to build a kindergarten school & $2006-2008$ & 300 & 18,000 \\
\hline Computer: two desktops and one laptop & 2010 & 30 & 1500 \\
\hline Construction of a new community house & 2010 & 40 & 2000 \\
\hline Study tour & 2010 & 80 & 4000 \\
\hline Fifteen tables and 15 chairs for local authorities & 2010 & 47 & 2350 \\
\hline Support for Hoa My kindergarten school & 2010 & 7 & 350 \\
\hline Direct support for national events held at primary and secondary schools & 2010 & 16 & 800 \\
\hline Provision of communication equipment for four community houses & 2010 & 5 & 250 \\
\hline Construct of a new community bridge & 2010 & 7 & 350 \\
\hline Computers: two desktops and one laptop & 2011 & 30 & 1500 \\
\hline Ten cows and eights pigs for breeding, along with cages & 2011 & 200 & 10,000 \\
\hline Direct support for national events held at primary and secondary schools & 2011 & 33 & 1650 \\
\hline Direct support for poor households & 2011 & 40 & 2000 \\
\hline Provision of communication equipment for four community houses & 2011 & 20 & 1000 \\
\hline Building of additional classrooms & 2011 & 180 & 9000 \\
\hline Upgrading a road An Lau-Que Phuong in 2013 (4.5 km) & $2012-2014$ & 7000 & 350,000 \\
\hline Concreting a road connecting Dan Thuong village to Que Phuong bridge & $2012-2014$ & 2500 & 125,000 \\
\hline Supporting the traditional medicine farm of the health clinic & $2012-2014$ & 10 & 500 \\
\hline Providing a rubbish collection for residents in 2013-2014 & $2012-2014$ & Not identify & Not identify \\
\hline
\end{tabular}

\section{References}

1. Hilson, G. Small-scale mining and its socio-economic impact in developing countries. Nat. Resour. Forum 2002, 26, 3-13. [CrossRef]

2. World Bank. The Extractive Industries Review: Striking a Better Balance; World Bank: Washington, DC, USA, 2004.

3. Sachs, J.D.; Warner, A.M. Natural Resource Abundance and Economic Growth; Harvard University: Cambridge, MA, USA, 1997.

4. Brunnschweiler, C.N. Cursing the Blessings? Natural Resource Abundance, Institutions, and Economic Growth. World Dev. 2008, 36, 399-419. [CrossRef]

5. Addison, T.; Boly, A.; Mveyange, A. The Impact of Mining on Spatial Inequality Recent Evidence from Africa. World Bank Policy Research Working Paper. 2017. Available online: https:/ / ssrn.com/abstract=2912611 (accessed on 24 April).

6. Auty, R.M. Sustaining Development in Mineral. Economies The Resource Curse Thesis; Routledge: London, UK, 1993.

7. Bebbington, A.; Abdulai, A.G.; Hinfelaar, M.; Humphreys Bebbington, D.; Sanborn, C. Political Settlements and the Governance of Extractive Industry: A Comparative Analysis of the Longue Durée in Africa and Latin America; ESID Working Paper No. 81; The University of Manchester: Manchester, UK, 2017.

8. Chuhan-Pole, P.; Dabalen, A.L.; Land, B.C.; Lewin, M.; Sanoh, A.; Smith, G.; Tolonen, A. Mining in Africa: Are Local Communities Better Off? World Bank: Washington, DC, USA, 2017.

9. Hilson, G. Small-scale mining, poverty and economic development in sub-Saharan Africa: An overview. Resour. Policy 2009, 34, 1-5. [CrossRef]

10. Kemp, D. Mining and community development: Problems and possibilities of local-level practice. Commun. Dev. J. 2010, 45, 198-218. [CrossRef]

11. Aragón, F.M.; Rud, J.P. Polluting Industries and Agricultural Productivity: Evidence from Mining in Ghana. Econ. J. 2016, 126, 1980-2011. [CrossRef]

12. Haslam McKenzie, F.M.; Hoath, A. The socio-economic impact of mine industry commuting labour force on source communities. Resour. Policy 2014, 42, 45-52. [CrossRef]

13. Horsley, J.; Prout, S.; Tonts, M.; Ali, S.H. Sustainable livelihoods and indicators for regional development in mining economies. Extr. Ind. Soc. 2015, 2, 368-380. [CrossRef] 
14. Tschakert, P.; Ricciardi, V.; Smithwick, E.; Machado, M.; Ferring, D.; Hausermann, H.; Bug, L. Situated knowledge of pathogenic landscapes in Ghana: Understanding the emergence of Buruli ulcer through qualitative analysis. Soc. Sci. Med. 2016, 150, 160-171. [CrossRef] [PubMed]

15. Visser, W. Corporate Social Responsibility in Developing Countries. In The Oxford Handbook of Corporate Social Responsibility; Crane, A., McWilliams, A., Matten, D., Moon, J., Siegel, D., Eds.; Oxford University Press: Oxford, UK, 2008; pp. 473-479.

16. Meesters, M.E.; Behagel, J.H. The Social Licence to Operate: Ambiguities and the neutralization of harm in Mongolia. Resour. Policy 2017, 53, 274-282. [CrossRef]

17. Manteaw, B. From tokenism to social justice: Rethinking the bottom line for sustainable community development. Commun. Dev. J. 2008, 43, 428-443. [CrossRef]

18. Hilson, G. Corporate Social Responsibility in the extractive industries: Experiences from developing countries. Resour. Policy 2012, 37, 131-137. [CrossRef]

19. Welker, M.A. "Corporate Security Begins in the Community": Mining, the Corporate Social Responsibility Industry, and Environmental Advocacy in Indonesia. Cult. Anthropol. 2009, 24, 142-179. [CrossRef]

20. Pimpa, N.; Moore, T.; Gregory, S.; Tenni, B. Corporate Social Responsibility and Mining Industry in Thailand. World J. Manag. 2015, 6, 34-47. [CrossRef]

21. Morris, J. The Vietnamese Bauxite Mining Controversy: The Emergence of a New Oppositional Politics; University of California: Berkeley, CA, USA, 2013.

22. Vo, M.; Brereton, D. Involuntary Resettlement in the Extractive Industries: Lessons from a Vietnamese Mining Project. In Governance of Extractive Industries: Assessing National Experiences to Inform Regional Cooperation in Southeast Asia; Evi, F., Francisca, S., Yesi, M., Eds.; Pernerbit Universitas Indonesia (UI Press): Jakarta, Indonesia, 2014.

23. Carlyle, A.T. Political Legitimacy of Vietnam's One Party-State: Challenges and Responses. J. Curr. Southeast Asian Aff. 2009, 28, 47-70.

24. Marston, H. Bauxite Mining in Vietnam's Central Highlands: An Arena for Expanding Civil Society? Contemp. Southeast. Asia 2012, 34, 173-196. [CrossRef]

25. Tran, T.T.; Nguyen, T.L.; Nguyen, V.D. Khoáng Sản-Phát Triển-Môi Trường: Đối Chiếu Giũua lý Thuyết và Thưc Tiễn; People and Nature Reconciliation: Ha Noi, Vietnam, 2012. Available online: http:/ /nature.org.vn/vn/ 2013/05/khoang-san-phat-trien-moi-truong/ (accessed on 24 April 2018).

26. Nguyen, N.B.; Boruff, B.; Tonts, M. Mining, development and well-being in Vietnam: A comparative analysis. Extr. Ind. Soc. 2017, 4, 564-575. [CrossRef]

27. Whitney, H. Vietnam: Water Pollution and Mining in an Emerging Economy. Asian Pacific Law Policy J. 2014, $15,25-57$.

28. Hoa, H. Sustainable Development and Exhaustible Resources-The Case of Bauxite Mining in VietNam. 2009. Available online: http:/ / corescholar.libraries.wright.edu/econ_student/87 (accessed on 24 April 2018).

29. Freudenburg, W.R.; Wilson, L.J. Mining the Data: Analyzing the Economic Implications of Mining for Nonmetropolitan Regions. Sociol. Inq. 2002, 72, 549-575. [CrossRef]

30. Frank, A.G. The Development of Underdevelopment. Mon. Rev. 1966, 18, 17-31. [CrossRef]

31. Godoy, R. Mining: Anthropological Perspectives. Ann. Rev. Anthropol. 1985, 14, 199-217. [CrossRef]

32. Ballard, C.; Banks, G. Resource Wars: The Anthropology of Mining. Ann. Rev. Anthropol. 2003, 32, $287-313$. [CrossRef]

33. Hilson, G.; Banchirigah, S.M. Are Alternative Livelihood Projects Alleviating Poverty in Mining Communities? Experiences from Ghana. J. Dev. Stud. 2009, 45, 172-196. [CrossRef]

34. Hilson, G. An overview of land use conflicts in mining communities. Land Use Policy 2002, 19, 65-73. [CrossRef]

35. Bebbington, A.; Hinojosa, L.; Bebbington, D.H.; Burneo, M.L.; Warnaars, X. Contention and Ambiguity: Mining and the Possibilities of Development. Dev. Chang. 2008, 39, 887-914. [CrossRef]

36. Garvin, T.; McGee, T.K.; Smoyer-Tomic, K.E.; Aubynn, E.A. Community-company relations in gold mining in Ghana. J. Environ. Manag. 2009, 90, 571-586. [CrossRef] [PubMed]

37. Hatcher, P. Taming Risks in Asia: The World Bank Group and New Mining Regimes. J. Contemp. Asia 2012, 42, 427-446. [CrossRef]

38. Bridge, G. Contested Terrain: Mining and the Environment. Ann. Rev. Environ. Resour. 2004, 29, $205-259$. [CrossRef] 
39. Aragón, F.M.; Rud, J.P. Natural Resources and Local Communities: Evidence from a Peruvian Gold Mine. Am. Econ. J. Econ. Policy 2013, 5, 1-25. [CrossRef]

40. Tonts, M.; Plummer, P.; Lawrie, M. Socio-economic wellbeing in Australian mining towns: A comparative analysis. J. Rural Stud. 2012, 28, 288-301. [CrossRef]

41. Eggert, R.G. Mining and Economic Sustainability: National Economies and Local Communities; Colorado School of Mines; IIED and Business Council for Sustainable Development: London, UK, 2001.

42. Rowley, T.; Sears, D.; Nelson, G.; Reed, J.; Yetley, M.; Goode, F. Rural Development Research: A Foundation for Policy; Greenwood Press: London, UK, 1996.

43. Randall, J.E.; Ironside, R.G. Communities on the Edge: An Economic Geography of Resource-Dependent Communities in Canada. Can. Geogr. 1996, 40, 17-35. [CrossRef]

44. Auty, R.M. Industrial policy reform in six large newly industrializing countries: The resource curse thesis. World Dev. 1994, 22, 11-26. [CrossRef]

45. Ross, M.L. What Have We Learned about the Resource Curse? Ann. Rev. Political Sci. 2015, 18, $239-259$. [CrossRef]

46. Hilson, G.; Maconachie, R. The Extractive Industries Transparency Initative: Panacea or White Elephant for Sub-Saharna Africa? In Mining, Society, and a Sustainable World; Richards, J., Ed.; Springer: Heidelberg, Germany, 2009.

47. Extractive Industries Transparency Initiative (EITI). Extractive Industries Transparency Initiative: Source Book; EITI: Oslo, Norway, 2005.

48. Weinthal, E.; Luong, P.J. Combating the Resource Curse: An Alternative Solution to Managing Mineral Wealth. Persp. Politic 2006, 4, 35-53. [CrossRef]

49. Natural Resource Governance Institute (NRGI). The Resource Curse: The Polititcal and Economic Challenges of Natural Resource Wealth; Natural Resource Governance Institute: New York, NY, USA, 2015.

50. World Commission on Environment and Development (WCED). Our Common Future ('Brundtland Report'); World Commission on Environment and Development/Oxford University Press: Oxford, UK, 1987.

51. United Nations (UN). United Nations Declaration on the Rights of Indigenous Peoples; United Nations: New York, NY, USA, 2007. Available online: http:/ / www.un.org/en/genocideprevention/documents/atrocity-crimes / Doc.18_declaration\%20rights\%20indigenous\%20peoples.pdf (accessed on 24 April 2018).

52. International Labour Organisation (ILO). C169-Indigenous and Tribal Peoples Convention, 1989 (No. 169); International Labour Organisation: Geneva, Switzerland, 1989. Available online: http:/ /www.ilo.org/dyn/ normlex/en/f?p=NORMLEXPUB:12100:0::NO::P12100_ILO_CODE:C169 (accessed on 24 April 2018).

53. Barrera-Hernández, L. Indigenous Peoples and Free, Prior, and Informed Consent in Latin America. In Sharing the Costs and Benefits of Energy and Resource Activity: Legal Change and Impact on Communities; Barrera-Hernández, L., Barton, B., Godden, L., Lucas, A., Rønne, A., Eds.; Oxford Scholarship; University of Oxford: Oxford, UK, 2016.

54. Barsh, R.L. MAking the Most of ILO Convention. Cultural Survival Quarterly Magazine, March 1994. Available online: https:/ /www.culturalsurvival.org/publications/cultural-survival-quarterly/makingmost-ilo-convention-169 (accessed on 24 April 2018).

55. MMSD. Breaking New Ground; EarthScan: London, UK, 2002.

56. Wheeler, D.; Fabig, H.; Boele, R. Paradoxes and Dilemmas for Stakeholder Responsive Firms in the Extractive Sector: Lessons from the Case of Shell and the Ogoni. J. Bus. Eth. 2002, 39, 297-318. [CrossRef]

57. Jenkins, H. Corporate social responsibility and the mining industry: Conflicts and constructs. Corp. Soc. Responsib. Environ. Manag. 2004, 11, 23-34. [CrossRef]

58. Hamann, R. Mining companies' role in sustainable development: The 'why' and 'how' of corporate social responsibility from a business perspective. Dev. S. Afr. 2003, 20, 237-254. [CrossRef]

59. Owen, J.R.; Kemp, D. Social licence and mining: A critical perspective. Resour. Policy 2013, 38, $29-35$. [CrossRef]

60. MMSD. Facing the future:The Report of the Mining, Minerals and Sustainable Development (MMSD) Australia Project; Earthscan Publications: London, UK, 2002.

61. Kapelus, P. Mining, Corporate Social Responsibility and the "Community": The Case of Rio Tinto, Richards Bay Minerals and the Mbonambi. J. Bus. Eth. 2002, 39, 275-296. [CrossRef]

62. Blowfield, M. CSR and Development: Is business appropriating global justice? Development 2004, 47, 61-68. [CrossRef] 
63. ChristianAid. Behind the Mask: The Real Face of CSR; ChristianAid: London, UK, 2004.

64. Bebbington, A.E.L.R. Social Conflict, Economic Development and the Extractive Industry; Routledge: London, UK, 2012.

65. Banks, G.; Ballard, C. The Ok Tedi Settlement: Issues, Outcomes, and Implications; National Centre for Development Studies, Research School of Pacific Studies, Australian National University: Canberra, Australia, 1997.

66. Kemp, D.; Owen, J.R.; Gotzmann, N.; Bond, C.J. Just Relations and Company-Community Conflict in Mining. J. Bus. Eth. 2011, 101, 93-109. [CrossRef]

67. Phelps, J.; Jones, C.A.; Pendergrass, J.A.; Gómez-Baggethun, E. Environmental liability: A missing use for ecosystem services valuation. Proc. Natl. Acad. Sci. USA 2015, 112, E5379. [CrossRef] [PubMed]

68. Morris, M.; Kaplinsky, R.; Kaplan, D. “One thing leads to another"—Commodities, linkages and industrial development. Resour. Policy 2012, 37, 408-416. [CrossRef]

69. Gaventa, J. Power and Powerlessness: Quiescence and Rebellion in an Appalachian Valley; Clarendon Press: Oxford, UK, 1980.

70. Tickamyer, A.R.; Duncan, C.M. Poverty and Opportunity Structure in Rural America. Ann. Rev. Sociol. 1990, 16, 67-86. [CrossRef]

71. Deaton, B.J.; Niman, E. An empirical examination of the relationship between mining employment and poverty in the Appalachian region. Appl. Econ. 2012, 44, 303-312. [CrossRef]

72. Duncan, C.M.; Coles, R. BLACKWELL: Rigid Classes and Corrupt Politics in Appalachia's Coal Fields. In Worlds Apart; Duncan, C.M., Ed.; Yale University Press: New Haven, CT, USA, 2014; pp. 1-72.

73. Bui, Q.B.; Le, T.H.; Tran, T.H.; Tran, T.K.; Pham, Q.T.; Dau, A.T. The Extractive Industries Transparency Initiative and the Implementation Perspective of Vietnam; Chamber of Commerce and Industry (VCCI) and Consultancy on Development (CODE): Hanoi, Vietnam, 2011. Available online: https:/ / eiti.org/sites/default/files/ documents/Vietnam-scoping.pdf (accessed on 24 April 2018).

74. Stevens, M.; Fulton, G. Technical Review of Bong Mieu Gold Project in Quang Nam Province, Vietnam for Olympus; Olympus Pacific Minerals Inc.: Toronto, ON, Canada, 2007.

75. Steven, M.; Fulton, G. Technical Report on Feasibility Studies for the Phuoc Son Gold Project in Quang Nam Province, Vietnam; Olympus Pacific Mineral Inc.: Auckland, New Zealand, 2008.

76. Olympus. Annual Information Form. for the Year Ended 31 December 2010; Olympus Pacific Minerals Inc.: Auckland, New Zealand, 2010.

77. Besra. Besra in Vietnam. 2016. Available online: http://www.besra.com/gold-mines-vietnam/ (accessed on 24 April 2018).

78. PSS. Statistics of Phuoc Son District in 2014; PSS: Tam Ky, Vietnam, 2015.

79. Pegg, S. Mining and poverty reduction: Transforming rhetoric into reality. J. Clean. Prod. 2006, 14, $376-387$. [CrossRef]

80. PNS. Statistics Book of Phu Ninh District 2014; Statistics, P.N., Ed.; PNS: Tam Ky, Vietnam, 2015.

81. Besra. Besra Suspends Operations in Vietnam. 2014. Available online: http://www.besra.com/besrasuspends-operations-vietnam/ (accessed on 24 April 2018).

82. Son, H. Hàng trăm người bao vây nhà máy vàng để đòi nợ. Available online: https: / / thanhnien.vn/thoisu/hang-tram-nguoi-bao-vay-nha-may-vang-de-doi-no-467762.html (accessed on 24 April 2018).

83. Besra. Besra Re-Opens Vietnam Gold Mine. 2016. Available online: http://www.besra.com/besra-re-opensvietnam-gold-mine/ (accessed on 24 April 2018).

84. PSGSO. Statistics Year Book 2014; PSGSO: Quang Nam, Vietnamese, 2015.

85. Nguyen, B.N.; Boruff, B.; Tonts, M. Indicators of mining in development: A Q-methodology investigation of two gold mines in Quang Nam province, Vietnam. Resour. Policy 2018. [CrossRef]

86. PSGC. Environmental Impact Assessment: Daksa Gold Project; Phuoc Son Gold Company: Tam Ky, Vietnam, 2010.

87. Ferguson, J. Expectations of Modernity: Myths and Meanings of Urban. Life on the Zambian Copperbelt; University of California Press: Berkeley, CA, USA, 1999.

88. Robbins, G. Mining FDI and urban economies in sub-Saharan Africa: Exploring the possible linkages. Local Econ. 2013, 28, 158-169. [CrossRef]

89. Junod, A.N.; Jacquet, J.B.; Fernando, F.; Flage, L. Life in the Goldilocks Zone: Perceptions of Place Disruption on the Periphery of the Bakken Shale. Soc. Natl. Resour. 2018, 31, 200-217. [CrossRef] 
90. Besra. Besra Completes Divestment of Vietnam Subsidiaries; 2017. Available online: http://www.besra. com/vn-sale-complete/ (accessed on 24 April 2018).

91. Campbell, B.; Akabzaa, T.M. Mining in Africa: Regulation and Development; Pluto Press, International Development Research Centre: Ottawa, ON, Canada, 2009.

92. World Bank. Nigeria-Poverty in the Midst of Plenty: The Challenge of Growth with Inclusion: A World Bank Poverty Assessment (English); World Bank: Washington, DC, USA, 1996.

93. Besra. Clean Drinking Water Is a Great Thing; 2017. Available online: http://www.besra.com/clean-waterinitiative/ (accessed on 24 April 2018).

(C) 2018 by the authors. Licensee MDPI, Basel, Switzerland. This article is an open access article distributed under the terms and conditions of the Creative Commons Attribution (CC BY) license (http://creativecommons.org/licenses/by/4.0/). 